\title{
EXAMINING GREEN HOTEL PATRONAGE INTENTION FROM THE PERSPECTIVE OF BEHAVIOURAL REASONING THEORY
}

\author{
Ling-Ling Tan* \\ Tunku Abdul Rahman University College, Malaysia \\ Norzalita Abd Aziz \\ Universiti Kebangsaan Malaysia, Malaysia \\ Abdul Hafaz Ngah \\ Universiti Malaysia Terengganu, Malaysia
}

\begin{abstract}
Green hotels help minimise the negative impact of consumption on the environment. This study examines consumers' intention to patronise green hotels by applying the Behavioural Reasoning Theory (BRT). In the BRT, the drivers of behavioural intentions include value, reasons for, reasons against as well as global motives (attitude). This study surveyed 262 respondents in the Klang Valley, Malaysia using questionnaires. The findings indicated that reasons serve as essential linkages between consumers' values and their attitudes. In particular, Attitude is the strongest predictor of green hotel patronage intention, followed by Reasons against Patronage, Altruism and Reasons for Patronage. Reasons against Patronage have a stronger influence on green hotel patronage intention than Reasons for Patronage. Marketers should minimise the effects of reasons against to improve green hotel patronage intention, promote consumer's altruism value and attitude toward choosing green hotels.
\end{abstract}

Keywords: Behavioural Reasoning Theory, Green Hotel Patronage Intention, Altruism, Reasons, Attitude.

Received: 12 December 2019

Accepted: 10 May 2021

https://doi.org/10.33736/ijbs.3766.2021

\section{INTRODUCTION}

The hospitality industry utilises a significant amount of natural resources, such as energy, water and other non-durable products, for their daily business operations (Chan et al., 2014). The industry also generates greenhouse gases and waste production (Alzboun et al., 2016). The growing awareness of environmental responsibility (Huang et al., 2014) and consumers' concern about the environment have led to the emergence of green hotels. Green hotels are lodging establishments that are committed to different environmental initiatives such as decreasing water and energy usage and minimising waste (Rahman \& Reynolds, 2016).

\footnotetext{
- Corresponding author: Faculty of Communication and Creative Industries, Tunku Abdul Rahman University College, Jalan Genting Kelang, Setapak, 53300 Kuala Lumpur. Tel: +603-41450123. E-mail: tanll@ tarc.edu.my
} 
The green consumerism movement is also spreading to emerging economies with the growth of consumers' knowledge about environmental protection (Yadav \& Pathak, 2016). In Malaysia, many green hotels and resorts are emerging (Yusof \& Jamaludin, 2014) and these green hotels such as Shangri-La's Rasa Ria Resort \& Spa, Kota Kinabalu; Shangri-La's Tanjung Aru Resort \& Spa; Frangipani Langkawi Resort \& Spa; The Shangri-La Hotel Kuala Lumpur; The Zenith Hotel, Kuantan; Borneo Tropical Rainforest Resort, Sarawak; The Shangri-La's Rasa Sayang Resort \& Spa Penang; Miri Marriot Resort \& Spa; Mandarin Oriental Kuala Lumpur; and Holiday Inn Resort Penang have won the ASEAN Green Hotel Award before (Tourism Malaysia, 2016). This shows that individual customers and businesses in Malaysia are aware of the green movement (Tan \& Yeap, 2012). However, green hotel businesses can be regarded still at an early stage in Malaysia (Mas'od \& Chin, 2014). Hence, understanding consumers' patronage intention is important.

Some studies state that consumers would select an eco-friendly hotel over a standard hotel (Gordon-Wilson \& Modi, 2015; Han et al., 2011; Manaktola \& Jauhari, 2007), while others show no preference for booking a green hotel (Chong \& Verma, 2013). Many consumers feel that addressing green issues can be a deprivation of comfort and luxury of the hospitality experience (Barber \& Deale, 2014). Guests are reluctant to pay for inconvenient green practices (Tang \& Lam, 2017).

Many people may have high environmental concern but feel that the preservation of the environment is the responsibility of the government or big organisations (Laroche et al., 2001). Previous research also proved that consumers may be concerned about environmental issues, but such concerns do not necessarily transform into green purchasing behaviors (Teng \& Chang, 2014). In other words, a high number of consumers state that they are willing to buy green products, but only a few actually make such purchases (Luchs et al., 2010). The response to environmental issues has been relatively slow in the hospitality industry as compared to the other industries (Park \& Kim, 2014).

Thus, it is essential to examine consumers' decision-making processes with regard to visiting a green hotel (Choi et al., 2015). Furthermore, consumer motives may differ between countries and culture, but earlier studies on green hotels are conducted in the context of developed nations (Yadav \& Pathak, 2017). By understanding the purchase intention of hotel consumers toward green hotels in developing countries like Malaysia, suitable green hospitality marketing strategies could be devised to influence patronage choices.

In addition, many past studies (i.e. Han et al., 2010; Yadav \& Pathak, 2017) have used and extended the theory of planned behaviour (TPB) (Ajzen, 1991) to understand consumers' intention/behaviour towards patronising green hotels. Behavioural intention theories are accepted and applied extensively in the social science context, but the behavioural intention models have not theoretically addressed if reason concepts offer unique insights into motivational mechanisms (Westaby, 2005a). This study uses the Behavioural Reasoning Theory (BRT) because it provides insights of decision-making that include the individual's context - "reasons for" and "reasons against" a particular behaviour in a single framework (Westaby, 2005a). In the psychology domain, adoption factors and anti-adoption factors may not be logically opposite to each other (Westaby et al., 2010). 
The objective of this study is to identify the psychological antecedents of green hotel patronage intention by using the Behavioural Reasoning Theory (Westaby, 2005a). Specifically, this study examines whether consumers' Altruism, Attitude, Reasons for Patronage and Reasons against Patronage influence their intention to patronise green hotels. This enables practitioners and policy makers to understand the motivational mechanisms of green hotel patronage and develop effective marketing strategies to promote positive purchasing intentions.

\section{LITERATURE REVIEW}

\subsection{The Behavioural Reasoning Theory}

The Behavioural Reasoning Theory (BRT) is the underpinning theory in this study. BRT posits that context-specific reasons are important in decision making, intention development and behaviour (Westaby et al., 2010). Past behavioural intention theories, such as the Theory of Reasoned Action and the Theory of Planned Behaviour, have not accounted for the effect of reasons in the process of decision making. Reasons, however, are proven important motivationally because they can be used to defend and justify an individual's actions (Pennington \& Hastie, 1988; Tetlock et al., 1989).

Therefore, this study examines green hotel patronage intention through the lens of BRT. BRT has proven to be a useful framework to explain the determinants of behavioural choices across different contexts ranging from technology adoption (Claudy et al., 2015; Gupta \& Arora, 2017; Sivathanu, 2018); leadership decision making (Westaby et al., 2010); renewable energy adoption (Claudy et al., 2013); urban bicycle commuting (Claudy \& Peterson, 2014) and charitable intention and behaviour (Nicholls \& Schimmel, 2016; Park et al., 2017). BRT's main premise is reasons function as essential antecedents of people's attitudes, intentions and behaviours. Reasons provide an additional relationship between values and global motives (attitudes). They directly influence attitude and intention to act through explicit and implicit processes (Westaby, 2005a).

Reasons are divided into two broad dimensions - reasons for the behaviour and reasons against the behaviour. These reasons for and reasons against can be represented by people's pro/con and benefit/cost explanations and also facilitator/constraint explanations (Westaby, 2005a). Hence, reasons in this study are separated into reasons for patronage (perceived green benefits) and reasons against patronage (perceived green costs).

\subsection{Attitude and Green Hotel Patronage Intention}

People develop attitudes toward purchasing a product or service by integrating their assessment of important aspects and outcomes of doing so (Fishbein \& Ajzen, 2009). An ecological attitude is developed through the individual's beliefs, concerns, values and intentions about environmental issues and behaviour (Schultz et al., 2004). Attitude was posited and confirmed as a predictor of behavioural intention in various domains (Ajzen, 2001; Westaby, 2005b).

Behavioural intentions are regarded as important factors in explaining consumers' behaviours because a certain behaviour is likely to be performed when an individual has a strong intention 
(Ajzen, 1991). Hence, consumers' positive intentions are essential for green hotels as the intentions indicate willingness for patronage. Prior studies (e.g. Teng et al., 2013; Verma \& Chandra, 2018) have demonstrated that attitude positively predicted green hotel visit intention. Thus, the researcher hypothesised that:

\section{Hypothesis 1: Attitude has a positive influence on Green Hotel Patronage Intention.}

\subsection{Reasons for/against Patronage and Attitude}

Reasons are defined as specific subjective factors individuals use to justify their anticipated behaviour and are theorised under two broad dimensions of reasons for and reasons against executing a behaviour (Westaby, 2005a). The reasons for and reasons against are conceptually distinct and include the cost-benefit as well as facilitating or constraining factors (Westaby, 2005a). In green hotel patronage intention, the reasons for patronage (perceived green benefits) consist of functional benefits, emotional benefits, social benefits and epistemic benefits (Jiang \& Kim, 2015). On the contrary, the reasons against patronage (perceived green costs) consist of high price premiums (e.g. Han et al., 2009; Jiang \& Kim, 2015; Li \& Wei, 2013); inconvenience (e.g. Barbarossa \& De Pelsmacker, 2016; Laroche et al., 2001; Rahman \& Reynolds, 2017); the cost of giving up comfort (Baker et al., 2014; Barber \& Deale, 2014) and the cost of giving up luxury (Baker et al., 2014; Barber \& Deale, 2014).

BRT hypothesises that context-specific reasoning influences the attitude toward the intentions because reasons are specific cognitions that are connected with the psychological concepts like sense-making and coherence (Westaby, 2005a). Previous studies (i.e. Claudy et al., 2015; Claudy \& Peterson, 2014; Gupta \& Arora, 2017; Sivathanu, 2018) confirmed the associations between Reasons for and Reasons against adoption with Attitude. Consistent with BRT, if an individual has many strong reasons (perceived green benefits) to patronise a green hotel, the higher the possibility the individual will possess a good attitude towards it and vice versa. Hence, the following hypotheses were developed:

\section{Hypothesis 2a: Reasons for patronage (Perceived green benefits) have a positive influence on Attitude.}

\section{Hypothesis 2b: Reasons against patronage (Perceived green costs) have a negative influence on Attitude.}

\subsection{Reasons for/against Patronage and Intention}

When individuals have justifiable reasons to support their anticipated behaviour they feel better about themselves (Westaby, 2005a). It is also more likely that an individual will choose a given decision alternative with confidence when the more an explanation is coherently reasonable with strongly supported reasons (Pennington \& Hastie, 1988). Reasons for have a significant direct positive influence, while Reasons against a significant direct negative influence on adoption intentions (Claudy et al., 2015; Claudy \& Peterson, 2014; Gupta \& Arora, 2017; Sivathanu, 2018). When considering a stay in a green hotel, the reasons for (perceived green benefits) refer to the benefits derived that contribute to the perceived value of green hotels. In contrast, what the 
consumers give up is the reasons against (perceived green costs) that deter them from staying in a green hotel. Thus, the following hypotheses were formed:

\section{Hypothesis 3a: Reasons for patronage (Perceived green benefits) have a positive influence on Green Hotel Patronage Intention. \\ Hypothesis 3b: Reasons against patronage (Perceived green costs) have a negative influence on Green Hotel Patronage Intention.}

\subsection{Altruism and Reasons for/against Patronage}

Altruism involves an innate concern about the society and the occupants' wellbeing (Stern et al., 1993). Today, many people know that their purchasing behaviours can affect the environment directly (Lee et al., 2010). Green purchasing behaviours preserve natural resources, protect the environment and are regarded to be a type of ethical consumer behaviours (Papaoikonomou et al., 2011). For many hotel firms that are involved in environmental programmes, altruism is an important motivator (Ayuso, 2006; Rivera \& de Leon, 2005). Altruism encourages individuals to perform prosocial consumption behaviours (Teng et al., 2013).

The expectancy-value theory premises that the beliefs that people hold about the expected outcome and the value of those outcomes have an important effect on the motivational process (Fishbein \& Ajzen, 1975). Consumers often activate cognitive processes such as values and beliefs that act as essential precursor to the reasons used by individuals to justify their behaviour (Westaby, 2005a). For example, people of Universalism values have stronger reasons to commute by bicycle, while people of Security values have stronger reasons against commuting by bicycle (Claudy \& Peterson, 2014).

Consumers take environmental issues as their purchase consideration to contribute to the global environment (Chen et al., 2015). Thus, altruistic people will be more willing to visit a green hotel as it benefits the environment. They are likely to purchase environmentally friendly hotel products and services as compared to the other alternatives (Laroche et al., 2001). They will have stronger reasons for or they will see more green benefits of patronising green hotels. On a similar vein, altruistic people will have lesser reasons against (perceived green costs) for visiting a green hotel. Thus, the following hypotheses were formulated.

Hypothesis 4a: Altruism has a positive influence on Reasons for

Patronage (Perceived green benefits).

Hypothesis 4b: Altruism has a negative influence on Reasons against

Patronage (Perceived green costs).

\subsection{Altruism and Green Hotel Patronage Intention}

Altruistic individuals are concerned about the welfare of the society and others (Stern et al., 1993) and they are motivated to execute prosocial consumption behaviours (Teng et al., 2013). Altruism positively influenced consumers' green behaviour (Stern et al., 1993), intention to buy green products (Mostafa, 2009) and intention to be environmentally responsible (Teng et al., 
2013). Individuals who value altruism will be more willing to visit a green hotel, an environmentally sustainable accommodation. Hence, the following hypothesis was postulated:

\section{Hypothesis 5: Altruism has a positive influence on Green Hotel Patronage Intention.}

\subsection{Altruism and Attitude}

In certain circumstances, reasons may not be fully activated and consumers may depend on heuristics motives (Kahneman et al., 1982), hence beliefs and values could have direct effect on attitude. This means that consumers can directly develop an attitude toward an object without justifying the expected behaviour in-depth. Altruism is applied in many prior studies to explore behaviours related to recycling, energy saving and environmental protection (Chen et al., 2015). Teng et al. (2013) revealed the direct effect of altruism on attitude. Individuals who are more sensitive to the threats of the environment assume greater moral responsibility to conserve the environment. Therefore, the following hypothesis was developed:

Hypothesis 6: Altruism has a positive influence on Attitude toward green hotel patronage intention.

Figure 1: Conceptual Framework

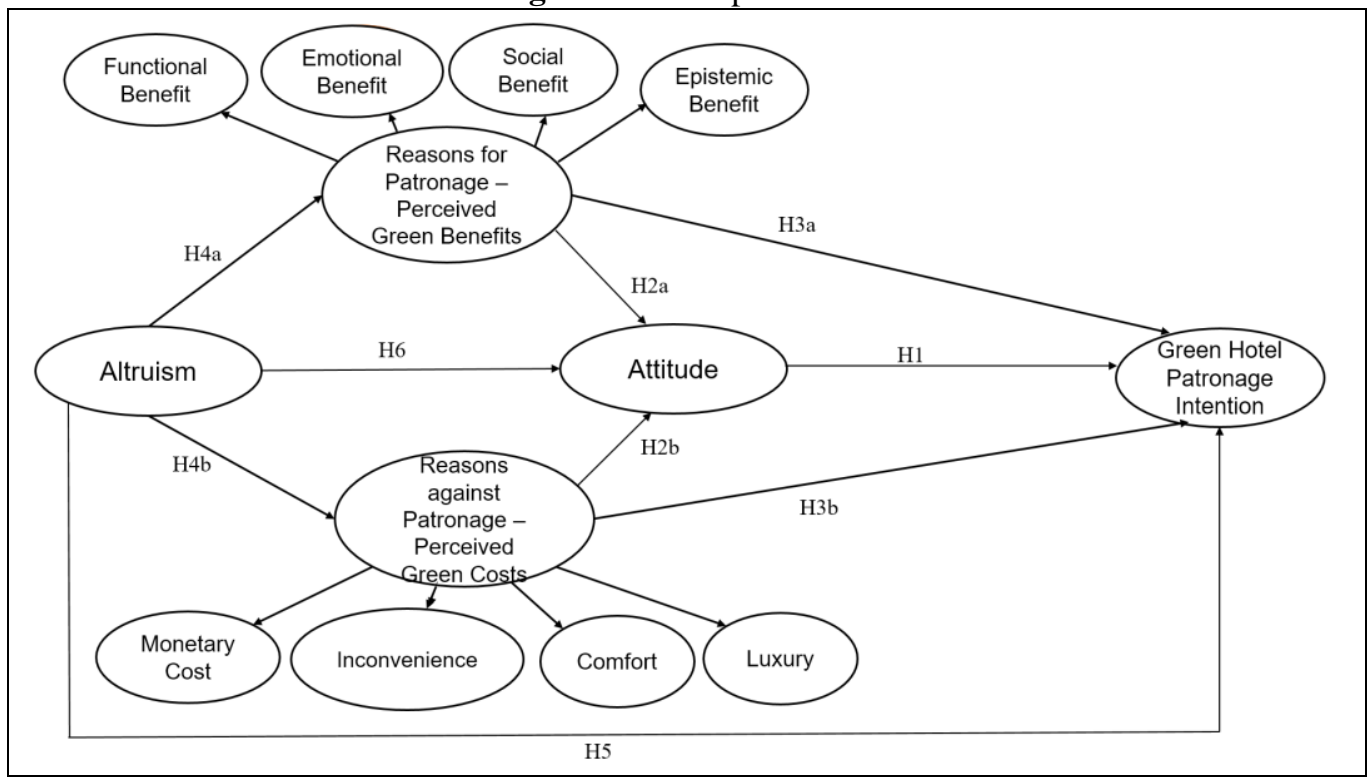




\section{METHODOLOGY}

\subsection{Sampling Technique and Data Collection}

The sampling technique employed was a combination of quota sampling and purposive sampling. As Malaysia is a multi-racial country, the quota sampling technique was used to secure consumer representation coverage across ethnicity and gender demographics. The respondents were selected non-randomly as there was no access to sampling frames. Four quotas were specified for the respondents' ethnicity, which was Bumiputera Malays (68.7\%), Chinese (22.9\%), Indians $(6.9 \%)$ and Others $(1.5 \%)$. The researcher set the ethnicity quotas of this study based on the ethnicity of the Malaysia population stated by the Department of Statistics Malaysia (2018). In addition, each quota will have an equal number of males (50\%) and females $(50 \%)$. At the same time, the purposive sampling technique was also applied because the respondents need to have knowledge about green hotels and have patronised conventional hotels within the past one year.

A pilot test was conducted on 30 respondents to ensure that the items in the questionnaire could be understood. The questionnaires were distributed physically to 300 potential consumers in the Klang Valley. Klang Valley is a significant urban agglomeration in Malaysia with an estimated population of 7.2 million (World Population Review, 2019). Face-to-face surveys were conducted by trained interviewers at six shopping mall locations in the Klang Valley to get data from a representative demographic profile. The respondents were intercepted at the entrance of the shopping malls. Those who agreed to participate and met the criteria set were given a stationery gift as a token of appreciation. The selected respondents need to have knowledge about green hotels and have stayed in conventional hotels within the past one year. They were also informed about the purpose of this survey and their responses will be kept confidential.

A total of 262 usable responses were received from the participants, garnering an $87.3 \%$ response rate. The number of responses collected fulfils the requirements of the minimum sample size to be employed by Partial Least Squares Structural Equation Modeling (PLS-SEM). As suggested by Hair et al. (2017a) and Hoyle (1995) respectively, 100 to 200 case are sufficient for a meaningful structural (or path) analysis.

The sample of this study consisted of Bumiputera Malays (68.7\%), Chinese (22.9\%), Indians $(6.9 \%)$ and Others $(1.5 \%)$. This sample also had an equal number of males $(50 \%)$ and females $(50 \%)$. Out of the 262 respondents, most of them have a monthly income of RM2000 - RM3999 (36.3\%) and RM4000 - RM5999 (24.4\%); a Bachelor's Degree (39.7\%) and work in the private sector $(61.5 \%)$. Table 1 showed the summary of the respondent's demographic information.

Table 1: Summary of Respondent's Demographic Information

\begin{tabular}{llll}
\hline \hline Demographic Information & & Frequency & Percentage (\%) \\
\hline Gender & Male & 131 & 50 \\
& Female & 131 & 50 \\
Ethnicity & Malay & 180 & 68.7 \\
& Chinese & 60 & 22.9 \\
& Indian & 18 & 6.9 \\
Age & Others & 4 & 1.5 \\
& $20-29$ years old & 106 & 40.5 \\
& $30-39$ years old & 77 & 29.4
\end{tabular}




\begin{tabular}{llll}
\hline \hline Demographic Information & Frequency & Percentage (\%) \\
\hline \multirow{5}{*}{ Monthly Income } & $40-49$ years old & 58 & 22.1 \\
& $50-59$ years old & 17 & 6.5 \\
& Above 60 years old & 4 & 1.5 \\
& Less than RM 1,000 & 19 & 7.3 \\
& RM 1,000 - RM 1,999 & 31 & 11.8 \\
& RM 2,000 - RM 3,999 & 95 & 36.3 \\
& RM 4,000 - RM 5,999 & 64 & 24.4 \\
& RM 6,000 - RM 7,999 & 25 & 9.5 \\
RM 8,000 - RM 9,999 & 9 & 3.4 \\
Work sector & RM 10,000 and above & 14 & 5.3 \\
& Private sector & 161 & 61.5 \\
& Government/Semi-government & 43 & 16.4 \\
& Own business & 30 & 11.5 \\
Education & Student & 14 & 5.3 \\
& Others & 14 & 5.3 \\
& Certificate/Diploma & 48 & 18.3 \\
& Bachelor's Degree & 104 & 39.7 \\
& Postgraduate Degree & 60 & 22.9 \\
& Others & 50 & 19.1 \\
\hline \hline
\end{tabular}

\subsection{Questionnaire Development}

The questionnaire was divided into two parts. The first part incorporated scales measuring Altruism, Reasons for Patronage (Perceived Green Benefits), Reasons against Patronage (Perceived Green Costs), Attitude and Green Hotel Patronage Intention. The second part of the questionnaire included the demographic section related to the respondents' gender, ethnicity, age, marital status, monthly income, occupation and highest education.

A five-point Likert scale, ranging from " 1 " strongly disagree to "5" strongly agree was used to measure Altruism; Reasons for Patronage (Perceived Green Benefits) - Functional Benefit, Emotional Benefit, Social Benefit, Epistemic Benefit; Reasons against Patronage (Perceived Green Costs) - Monetary Cost, Inconvenience, Comfort and Luxury as well as Attitude. Meanwhile, Green Hotel Patronage Intention, the endogenous variable, was measured using a seven-point Likert scale, ranging from " 1 " strongly disagree to "7" strongly agree. Two scales were used to reduce method biases caused by commonalities in scale endpoints (Podsakoff et al., 2003).

This study also used the Harman's single factor test to detect the issue of common method variance. Common method variance needs to be examined because the predictor and criterion variables in the questionnaire are collected from the same individual (Podsakoff et al., 2003). This is conducted by entering all the principal constructs into a principal component factor analysis (Podsakoff \& Organ, 1986). Based on the results, the single factor only explains $31.5 \%$ of the variance, therefore common method bias is not a serious problem in this study.

Altruism, consisted of two indicators, was adapted from Teng et al. (2013). The dimensions for Reasons for Patronage (Perceived Green Benefits) - Functional Benefit, Emotional Benefit, Social Benefit, Epistemic Benefit were measured by adapting indicators suggested by Jiang and 
Kim (2015). For the Reasons against Patronage Dimensions, Monetary Cost was adapted from Jiang and Kim (2015); Inconvenience from Laroche et al. (2001); Comfort and Luxury were both from Baker et al. (2014). Attitude was measured using four indicators adopted from Teng et al. (2013). Finally, Green Hotel Patronage Intention's indicators were adopted from Chen and Tung (2014). The expressions of the items were modified, where appropriate, to suit the content of green hotels.

\section{RESULTS AND DISCUSSION}

To test the developed model, the Partial Least Squares (PLS) based SEM (PLS-SEM) approach was used. PLS is a second-generation model multivariate technique (Hair et al., 2012) that can simultaneously assess the measurement model and the structural model with the aim of minimising the error variance (Hair et al., 2014). The data was analysed using the Smart PLS Version 3.2.8 (Ringle et al., 2015). Following the suggestions of Hair et al. (2014), the bootstrapping method was used. 500 resamples was used to determine the significance levels for loadings and path coefficients (Ramayah et al., 2018) as 500 is still larger than the total observations in this study.

\subsection{Measurement Model}

To evaluate convergent validity, Hair et al. (2014) suggested the use of factor loadings, composite reliability (CR) and average variance extracted (AVE). The recommended values for loadings are $>0.5$, the AVE $>0.5$ and the CR $>0.7$. Figure 1 showed that Reasons for Patronage (Perceived Green Benefits) (RF) and Reasons against Patronage (Perceived Green Costs) (RA) are conceptualised as second-order constructs. The reasons for and reasons against green hotel patronage intention are modelled individually as second order constructs (Marsh \& Hocevar, 1985) to provide a more parsimonious model (Chen et al., 2005). Hence, the repeated indicator approach is used to model the second-order factors (Reflective-Reflective) in the PLS analysis. The results in Table 2 showed that the measurement model exceeded the recommended values, therefore proving sufficient convergent validity.

Table 2: Measurement Model

\begin{tabular}{|c|c|c|c|c|c|}
\hline $\begin{array}{l}\text { First-order } \\
\text { Constructs }\end{array}$ & $\begin{array}{l}\text { Second-order } \\
\text { Construct }\end{array}$ & Item & Loadings & AVE & $\mathbf{C R}$ \\
\hline \multirow{2}{*}{ Altruism } & & AL1 & 0.936 & 0.872 & 0.932 \\
\hline & & AL2 & 0.931 & & \\
\hline \multirow{5}{*}{ Functional Benefit } & & FU1 & 0.736 & 0.644 & 0.900 \\
\hline & & FU2 & 0.749 & & \\
\hline & & FU3 & 0.855 & & \\
\hline & & FU4 & 0.847 & & \\
\hline & & FU5 & 0.816 & & \\
\hline \multirow{3}{*}{ Emotional Benefit } & & EM1 & 0.892 & 0.785 & 0.916 \\
\hline & & EM2 & 0.912 & & \\
\hline & & EM3 & 0.853 & & \\
\hline \multirow{2}{*}{ Social Benefit } & & S1 & 0.863 & 0.779 & 0.914 \\
\hline & & S2 & 0.897 & & \\
\hline
\end{tabular}




\begin{tabular}{|c|c|c|c|c|c|}
\hline $\begin{array}{l}\text { First-order } \\
\text { Constructs } \\
\end{array}$ & $\begin{array}{l}\text { Second-order } \\
\text { Construct }\end{array}$ & Item & Loadings & AVE & CR \\
\hline & & S3 & 0.888 & & \\
\hline \multirow{10}{*}{ Epistemic Benefit } & & EP1 & 0.916 & 0.816 & 0.930 \\
\hline & & $\mathrm{EP} 2$ & 0.912 & & \\
\hline & & EP3 & 0.881 & & \\
\hline & Reasons for & Functional & 0.885 & 0.708 & 0.907 \\
\hline & $\begin{array}{l}\text { Patronage } \\
\text { (Perceived Green } \\
\text { Benefits) }\end{array}$ & Benefit & & & \\
\hline & & Emotional & & & \\
\hline & & Benefit & 0.791 & & \\
\hline & & Social Benefit & 0.849 & & \\
\hline & & Epistemic & & & \\
\hline & & Benefit & 0.839 & & \\
\hline \multirow{3}{*}{ Monetary Cost } & & M1 & 0.757 & 0.594 & 0.814 \\
\hline & & M2 & 0.779 & & \\
\hline & & M3 & 0.776 & & \\
\hline \multirow{4}{*}{ Inconvenience } & & I1 & 0.846 & 0.667 & 0.889 \\
\hline & & $\mathrm{I} 2$ & 0.876 & & \\
\hline & & $\mathrm{I} 3$ & 0.790 & & \\
\hline & & I4 & 0.749 & & \\
\hline \multirow{3}{*}{ Comfort } & & $\mathrm{C} 1$ & 0.903 & 0.841 & 0.941 \\
\hline & & $\mathrm{C} 2$ & 0.929 & & \\
\hline & & $\mathrm{C} 3$ & 0.919 & & \\
\hline \multirow{9}{*}{ Luxury } & & L1 & 0.865 & 0.699 & 0.874 \\
\hline & & $\mathrm{L} 2$ & 0.864 & & \\
\hline & & L3 & 0.776 & & \\
\hline & Reasons against & Monetary & 0.570 & 0.529 & 0.815 \\
\hline & Patronage & Cost & & & \\
\hline & $\begin{array}{l}\text { (Perceived Green } \\
\text { Costs) }\end{array}$ & & & & \\
\hline & & Inconvenience & 0.734 & & \\
\hline & & Comfort & 0.729 & & \\
\hline & & Luxury & 0.849 & & \\
\hline \multirow{4}{*}{ Attitude } & & AT1 & 0.896 & 0.765 & 0.929 \\
\hline & & AT2 & 0.851 & & \\
\hline & & AT3 & 0.885 & & \\
\hline & & AT4 & 0.867 & & \\
\hline \multirow{3}{*}{ Patronage Intention } & & PI1 & 0.868 & 0.821 & 0.932 \\
\hline & & PI2 & 0.941 & & \\
\hline & & $\mathrm{PI} 3$ & 0.908 & & \\
\hline
\end{tabular}

Note: $\mathrm{AVE}=$ average variance extracted; $\mathrm{CR}=$ composite reliability

After confirming the convergent validity, the discriminant validity was assessed using the Heterotrait-Monotrait Ratio (HTMT) method as proposed by Hair et al. (2017b). Table 3 showed that all the pairs of constructs in the matrix format are below 0.85 (Kline, 2011), which demonstrates that the measures used in this study are distinct with no discriminant validity issue. 
Table 3: Discriminant Validity - HTMT

\begin{tabular}{|c|c|c|c|c|c|c|c|c|c|c|c|}
\hline & 1 & 2 & 3 & 4 & 5 & 6 & 7 & 8 & 9 & 10 & 11 \\
\hline \multicolumn{12}{|l|}{ Altruism (1) } \\
\hline Attitude (2) & 0.488 & & & & & & & & & & \\
\hline Comfort (3) & 0.102 & 0.292 & & & & & & & & & \\
\hline $\begin{array}{l}\text { Emotional } \\
\text { Benefit (4) }\end{array}$ & 0.582 & 0.538 & 0.136 & & & & & & & & \\
\hline $\begin{array}{l}\text { Epistemic } \\
\text { Benefit (5) }\end{array}$ & 0.745 & 0.630 & 0.126 & 0.670 & & & & & & & \\
\hline $\begin{array}{l}\text { Functional } \\
\text { Benefit (6) }\end{array}$ & 0.668 & 0.723 & 0.149 & 0.674 & 0.720 & & & & & & \\
\hline $\begin{array}{l}\text { Green Hotel } \\
\text { Patronage }\end{array}$ & & & & & & & & & & & \\
\hline Intention (7) & 0.551 & 0.745 & 0.309 & 0.481 & 0.540 & 0.569 & & & & & \\
\hline $\begin{array}{c}\text { Inconvenience } \\
\text { (8) }\end{array}$ & 0.080 & 0.124 & 0.284 & 0.068 & 0.084 & 0.073 & 0.184 & & & & \\
\hline Luxury (9) & 0.088 & 0.230 & 0.643 & 0.074 & 0.042 & 0.061 & 0.328 & 0.597 & & & \\
\hline $\begin{array}{l}\text { Monetary } \\
\text { Cost (10) }\end{array}$ & 0.191 & 0.138 & 0.252 & 0.153 & 0.199 & 0.177 & 0.212 & 0.413 & 0.464 & & \\
\hline $\begin{array}{c}\text { Social Benefit } \\
\text { (11) }\end{array}$ & 0.617 & 0.642 & 0.114 & 0.667 & 0.719 & 0.790 & 0.596 & 0.100 & 0.066 & 0.150 & \\
\hline
\end{tabular}

Once the measurement model is confirmed, the lateral collinearity test (VIF) was done to check that there is no collinearity issue in the model before continuing with the structural model. VIF values higher than 3.3 have a potential collinearity issue (Diamantopoulos \& Siguaw, 2006). Table 4 showed that all VIF values were lower than 3.3, revealing that lateral multicollinearity was not a problem for this study.

\subsection{Structural Model}

When assessing the structural model, Hair et al. (2017b) proposed to look at the standard beta, $t$ values from a bootstrapping procedure with a resample more than the actual respondents, confidence intervals, $\mathrm{Q}^{2}$ that relates to the predictive relevance and $\mathrm{f}^{2}$ that looks at effect sizes.

The hypotheses were tested by analysing the $\mathrm{t}$ values and path coefficients of the proposed research model. Table 5 showed the results of the hypothesis testing. Green Hotel Patronage Intention was found to be predicted by Attitude $(\mathrm{H} 1: \beta=0.457, \mathrm{t}=6.692: \mathrm{LL}=0.347, \mathrm{UL}=$ 0.567, $\mathrm{p}<0.01$ ); Reasons against Patronage (H3b: $\beta=-0.185, \mathrm{t}=3.423$ : $\mathrm{LL}=-0.283$, UL $=-$ 0.103, $\mathrm{p}<0.01$ ); Altruism (H5 $\beta=0.173, \mathrm{t}=2.581: \mathrm{LL}=0.066, \mathrm{UL}=0.293, \mathrm{p}<0.01)$ and Reasons for Patronage $(\mathrm{H} 3 \mathrm{a}: \beta=0.141, \mathrm{t}=1.658 \mathrm{LL}=0.015, \mathrm{UL}=0.270, \mathrm{p}<0.05)$. Among these independents, Attitude has the best ability to predict the behavioural intention of patronising a green hotel. The findings suggest that consumers with more favourable attitude toward green hotel would have higher intention to patronise a green hotel. Reasons against Patronage have a stronger significant influence on green hotel patronage intention than Reasons for Patronage. Besides a direct effect for the relationship between altruism and green hotel patronage intention, 
Table 4: Multicollinearity

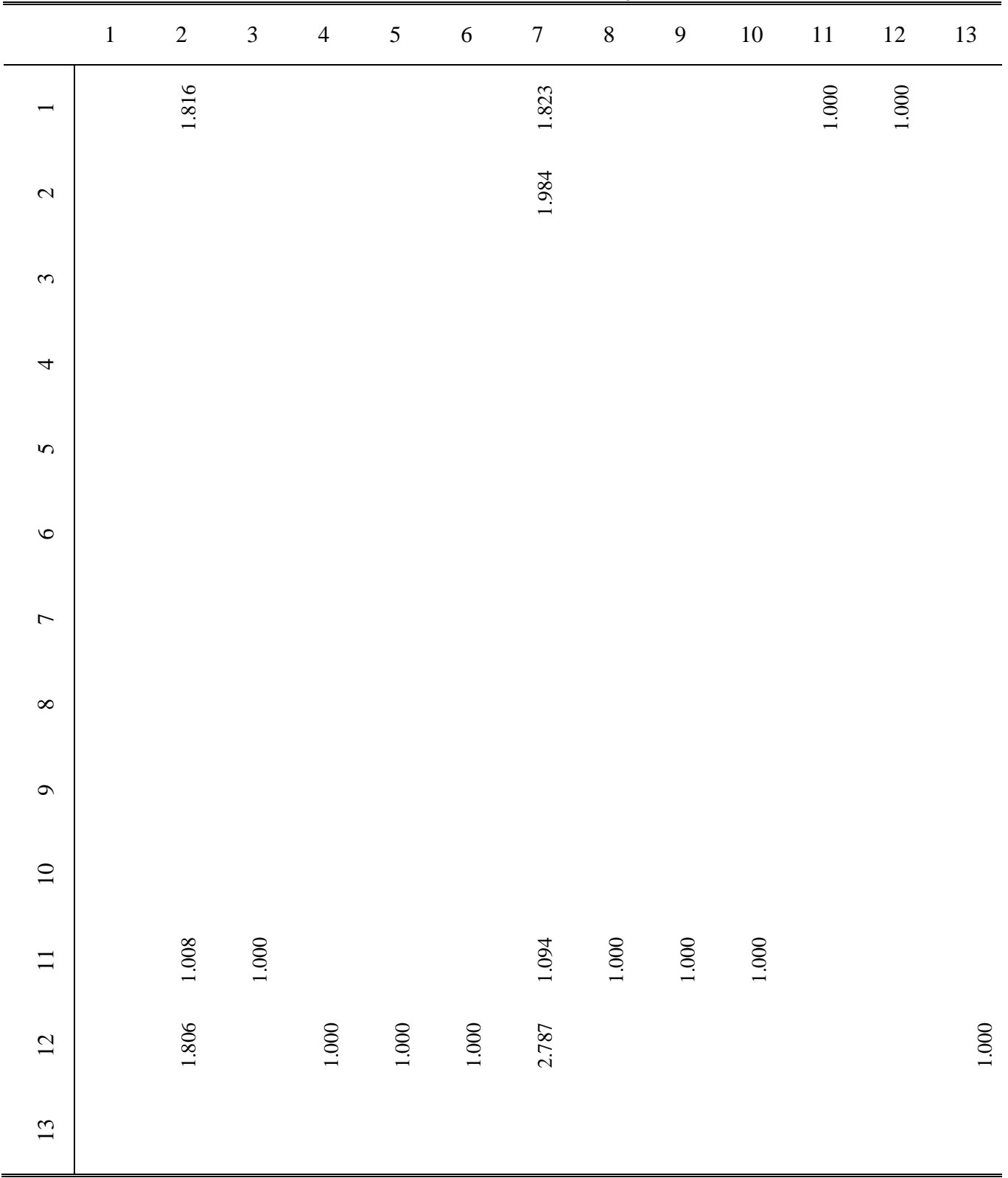

Note: 1 = Altruism; 2 = Attitude; 3 = Comfort; 4 = Emotional Benefit; 5 = Epistemic Benefit; 6 = Functional Benefit; 7 = Green Hotel Patronage Intention; $8=$ Inconvenience; 9 = Luxury; $10=$ Monetary Cost; 11 = Reasons against Patronage; $12=$ Reasons for Patronage; $13=$ Social Benefit.

Altruism also significantly influences Reasons for Patronage $(\mathrm{H} 4 \mathrm{a} \beta=0.668, \mathrm{t}=12.536$ : $\mathrm{LL}=$ $0.573, \mathrm{UL}=0.746, \mathrm{p}<0.01)$. 
In addition, reasons are context specific and are salient predictors of Attitude besides green hotel patronage intention. It was found that Reasons for Patronage have a positive effect $(\mathrm{H} 2 \mathrm{a}: \beta=$ 0.703, $\mathrm{t}=12.334: \mathrm{LL}=0.618, \mathrm{UL}=0.794, \mathrm{p}<0.01)$ and Reasons against Patronage have a negative effect $(\mathrm{H} 2 \mathrm{~b}: \beta=-0.208, \mathrm{t}=4.477$ : $\mathrm{LL}=-0.284, \mathrm{UL}=-0.133, \mathrm{p}<0.01)$ toward Attitude.

Table 5: Results of Hypothesis Testing

\begin{tabular}{|c|c|c|c|c|c|c|c|c|}
\hline Hypothesis & Path & Beta & SE & t-value & $\begin{array}{l}\mathbf{p} \\
\text { value }\end{array}$ & $\mathbf{L L}$ & UL & Results \\
\hline \multicolumn{9}{|l|}{$\mathrm{H} 1$} \\
\hline & $\begin{array}{l}\text { Attitude -> Green } \\
\text { Hotel Patronage } \\
\text { Intention }\end{array}$ & 0.457 & 0.068 & 6.692 & 0.000 & 0.347 & 0.567 & supported \\
\hline \multicolumn{9}{|l|}{$\mathrm{H} 2 \mathrm{a}$} \\
\hline & $\begin{array}{l}\text { Reasons for } \\
\text { Patronage -> } \\
\text { Attitude }\end{array}$ & 0.703 & 0.057 & 12.334 & 0.000 & 0.618 & 0.794 & supported \\
\hline \multicolumn{9}{|l|}{$\mathrm{H} 2 \mathrm{~b}$} \\
\hline & $\begin{array}{l}\text { Reasons against } \\
\text { Patronage -> } \\
\text { Attitude }\end{array}$ & -0.208 & 0.046 & 4.477 & 0.000 & -0.284 & -0.133 & supported \\
\hline \multicolumn{9}{|l|}{$\mathrm{H} 3 \mathrm{a}$} \\
\hline & $\begin{array}{l}\text { Reasons for } \\
\text { Patronage -> }\end{array}$ & & & & & & & \multirow[b]{2}{*}{ supported } \\
\hline & $\begin{array}{l}\text { Green Hotel } \\
\text { Patronage } \\
\text { Intention }\end{array}$ & 0.141 & 0.085 & 1.658 & 0.049 & 0.015 & 0.270 & \\
\hline \multicolumn{9}{|l|}{$\mathrm{H} 3 \mathrm{~b}$} \\
\hline & Reasons against & & & & & & & \multirow{4}{*}{ supported } \\
\hline & Patronage -> & & & & & & & \\
\hline & Green Hotel & & & & & & & \\
\hline & $\begin{array}{l}\text { Patronage } \\
\text { Intention }\end{array}$ & -0.185 & 0.054 & 3.423 & 0.000 & -0.283 & -0.103 & \\
\hline \multicolumn{9}{|l|}{$\mathrm{H} 4 \mathrm{a}$} \\
\hline & $\begin{array}{l}\text { Altruism -> } \\
\text { Reasons for } \\
\text { Patronage }\end{array}$ & 0.668 & 0.053 & 12.536 & 0.000 & 0.573 & 0.746 & supported \\
\hline \multirow[t]{2}{*}{$\mathrm{H} 4 \mathrm{~b}$} & & & & & & & & \\
\hline & $\begin{array}{l}\text { Altruism -> } \\
\text { Reasons against } \\
\text { Patronage }\end{array}$ & -0.085 & 0.057 & 1.482 & 0.069 & -0.169 & 0.022 & ns \\
\hline \multirow[t]{3}{*}{ H5 } & Altruicm & & & & & & & \multirow{3}{*}{ supported } \\
\hline & $\begin{array}{l}\text { Altruism -> } \\
\text { Green Hotel }\end{array}$ & & & & & & & \\
\hline & $\begin{array}{l}\text { Patronage } \\
\text { Intention }\end{array}$ & 0.173 & 0.067 & 2.581 & 0.005 & 0.066 & 0.293 & \\
\hline \multirow[t]{2}{*}{ H6 } & & & & & & & & \multirow[t]{2}{*}{ ns } \\
\hline & $\begin{array}{l}\text { Altruism -> } \\
\text { Attitude }\end{array}$ & -0.059 & 0.070 & 0.845 & 0.199 & -0.190 & 0.041 & \\
\hline
\end{tabular}


Table 6 presents the values of the coefficient of determination $\left(\mathrm{R}^{2}\right)$, the effect size $\left(\mathrm{f}^{2}\right)$, and the predictive relevance $\left(\mathrm{Q}^{2}\right)$ of exogenous variables on the endogenous variable. The $\mathrm{R}^{2}$, which shows the amount of variance explained by the exogenous variables, is calculated to determine the structural models' predictive power. The $\mathrm{R}^{2}$ obtained was 0.527 . This finding implies that Altruism, Reasons for Patronage, Reasons against Patronage and Attitude explained 52.7 per cent of the variance in Green Hotel Patronage Intention.

Figure 2: Structural Model

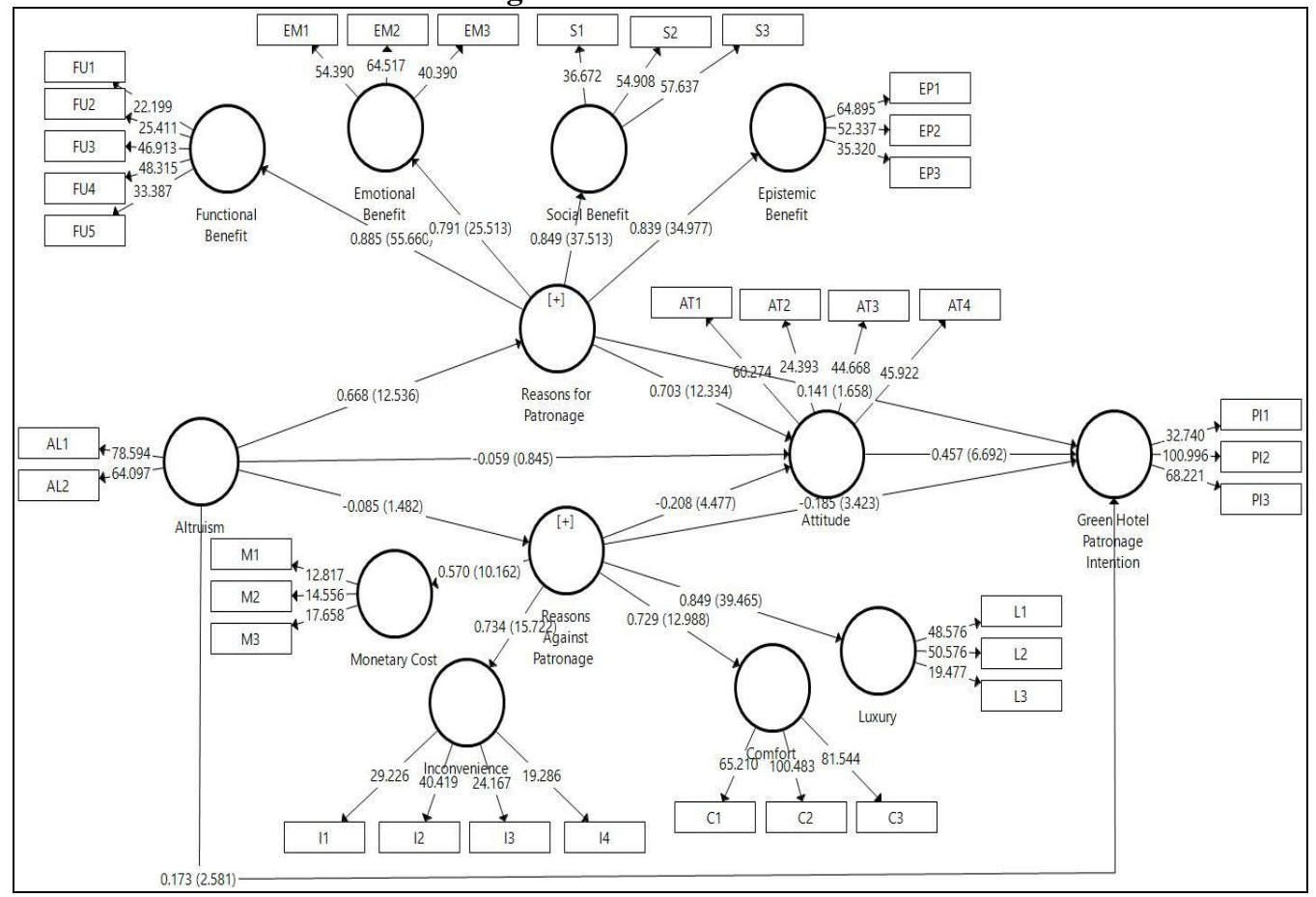

The $\mathrm{Q}^{2}$ for Green Hotel Patronage Intention is 0.405 , which is higher than 0 (Hair et al., 2017b), suggesting that Altruism, Attitude, Reasons for Patronage and Reasons against Patronage have a predictive ability on the intention to patronise green hotel. The effect size $f^{2}$ is interpreted as having substantial effect with a value of 0.35 , medium effect with a value of 0.15 and small effect with a value of 0.02 (Cohen, 1988). Among the endogenous variables, Attitude has a medium effect, while Altruism, Reasons for Patronage and Reasons against Patronage have a small effect on the intention to patronise green hotel.

Table 6: Coefficient of Determination $\left(\mathrm{R}^{2}\right)$, Effect Size $\left(\mathrm{f}^{2}\right)$ and Predictive Relevance $\left(\mathrm{Q}^{2}\right)$

\begin{tabular}{llll}
\hline Construct & R Square & Q Square & f Square \\
\hline Green Hotel Patronage Intention & 0.527 & 0.405 & \\
Altruism & & & 0.035 (small) \\
Attitude & 0.496 & 0.349 & 0.223 (medium) \\
Reasons for Patronage & 0.446 & 0.215 & 0.015 (small) \\
Reasons against Patronage & 0.007 & 0.002 & 0.66 (small) \\
\hline
\end{tabular}




\section{CONCLUSION, LIMITATIONS AND RECOMMENDATIONS}

This study confirms that "reasons against" patronage have a stronger significant influence on green hotel patronage intention than the "reasons for". The framework shows the difference between the "reasons for" (perceived green benefits) and "reasons against" (perceived green costs) factors were not merely logical opposite of each other. Thus, communicating benefits alone to the consumers would by myopic. Marketers should also pay attention to the perceived green costs and develop suitable strategies to address these factors that slow the adoption of green hotels.

Green hotel patronage intentions are also influenced by Altruism and Attitude. The results of this study support the role of altruism in influencing green hotel patronage intention. This is similar to the finding of Teng et al. (2013) who stated that individuals who showed positive altruistic value are likely to perceive the patronage of a green hotel as highly important to society. Thus, green hotel managers should stimulate altruistic values of people on green hotel patronage. Their strategies could target potential consumers who are altruistic, such as members of green, environmental or non-profit organisations.

Related government agencies could promote campaigns that cultivate altruistic minds. The target audience for such campaigns should be teenage students. They will have more intention to patronise a green hotel when they understand that this sustainable behaviour will not only benefit themselves but also the environment.

Attitude also positively influenced green hotel patronage intention. This finding is similar to the results of other studies such as Chen and Tung (2014); Han et al. (2010); Teng et al. (2013); Verma and Chandra (2018). In this study, Attitude is the strongest predictor of green hotel patronage as compared to Altruism, Reasons for and Reasons against. Thus, promoting a favourable attitude toward green hotels is important. As attitude is also influenced by both reasons for and reasons against, green hoteliers should highlight the perceived benefits of green hotels and simultaneously address the perceived explicit and implicit costs of the consumers.

Green hoteliers should highlight the benefits consumers will get from patronising green hotels through their different forms of marketing communication. Green-related behaviour is prompted by a complex pattern of cognitive (i.e. perceived value and perceived cost) and affective (i.e. anticipated positive/negative emotion) elements (Han et al., 2015). Hence, green hoteliers should stress their functional benefits such as improved indoor air quality, use of natural fibre linens to reduce sensitive skin issues and fresh organic food. Besides functional benefit, the epistemic benefits include being able to familiarise oneself with protecting the environment and getting to know the green practices implemented by green hotels.

To evoke positive emotions, green hoteliers can focus on the emotional and social benefits. Green hoteliers can emphasise on the moral satisfaction gained from doing good to the environment and future generations by patronising a green hotel. For social benefit, green hoteliers can highlight to customers that patronising green hotels is an environmental contribution acknowledged or admired by others. These reasons for patronage will make the trade-off between the "get" and "give" components worth it. Although the price of a green hotel is higher, consumers can enjoy the green benefits from their stay in a green hotel. 
For consumers who are willing to accept inconvenience and sacrifice their comfort, green hoteliers can provide affordable eco-friendly alternatives that could lead to savings. Discounts can be given to consumers who do not ask for a daily change of towels. Green hoteliers can also hold sales promotion programme to encourage consumers to stay in green hotels. Consumers who take up the sales promotion offer can be requested to post and share content about their stay, the hotel environment and service.

Although altruism positively predicts green hotel patronage intention, it does not influence a favourable attitude toward green hotel. Similarly, altruism also does not influence Reasons against Patronage. A consumer may be altruistic and perform environmentally sustainable act such as recycling waste, saving resources, but he or she may still have a negative attitude toward green hotels and hold strong reasons against patronage. Green hoteliers need to convince consumers that their choice in patronising green hotels does help conserve the environment. Consumer skepticism about green claim can affect the purchase behaviour and loyalty toward green products (Chan \& Wong, 2012). Some hotels may share false information about their green practices while they conceal the real motives for requesting consumers to turn off the lights and recycle towels (Sukhu \& Scharff, 2018).

Thus, it is important that hotels put in effort to integrate environmentally friendly practices that establish credibility in consumers' minds. Green hoteliers can share their green initiatives in helping to improve environmental degradation. They can also hold campaigns on environmental education to assure consumers that the change in buying behaviour in a more environmentally friendly way, such as patronising green hotels, helps protect the environment.

This study has several limitations that may create further research avenues. Although the empirical findings of this study contribute to the existing literature, the findings of this study may be limited to the sample. Data was collected from consumers in the Klang Valley, Malaysia, a developing country, thus the findings should be verified for other cities or countries.

This study examines the reasoning constructs to explain green hotel patronage intention. It does not cover the actual patronage behaviour which can be examined in other studies. Therefore, other researchers could test the BRT that describes the relations between people's beliefs/values, reasons, global motives, intention and behaviour in other domains.

\section{ACKNOWLEDGEMENT}

This paper is revised and rewritten based on the paper presented at the International Symposium on Applied Structural Equation Modeling and Methodological Matters (SASEM) 2019 which was held at Novotel, Melaka from 21 - 24 August 2019.

\section{REFERENCES}

Ajzen, I. (1991). The theory of planned behavior. Organizational Behavior and Human Decision Processes, 50(2), 179-211.

Ajzen, I. (2001). Nature and operation of attitudes. Annual Review of Psychology, 52(1), 27-58. 
Alzboun, N., Khawaldah, H., Backman, K., \& Moore, D. (2016). The effect of sustainability practices on financial leakage in the hotel industry in Jordan. Journal of Hospitality and Tourism Management, 27, 18-26.

Ayuso, S. (2006). Adoption of voluntary environmental tools for sustainable tourism: Analysing the experience of Spanish hotels. Corporate Social Responsibility and Environmental Management, 13(4), 207-220.

Baker, M. A., Davis, E. A., \& Weaver, P. A. (2014). Eco-friendly attitudes, barriers to participation, and differences in behavior at green hotels. Cornell Hospitality Quarterly, 55(1), 89-99.

Barbarossa, C., \& De Pelsmacker, P. (2016). Positive and negative antecedents of purchasing eco-friendly products: A comparison between green and non-green consumers. Journal of Business Ethics, 134(2), 229-247.

Barber, N., \& Deale, C. (2014). Tapping mindfulness to shape hotel guests' sustainable behavior. Cornell Hospitality Quarterly, 55(1), 100-114.

Chan, E. S., Hon, A. H., Chan, W., \& Okumus, F. (2014). An empirical study of environmental practices and employee ecological behavior in the hotel industry. Journal of Hospitality and Tourism Research, 41(5), 585-608.

Chan, T. \& Wong, C. W. Y. (2012). The consumption side of sustainable fashion supply chain: Understanding fashion consumer eco-fashion consumption decision. Journal of Fashion Marketing and Management: An International Journal, 16(2), 193-215.

Chen, F. F., Sousa, K. H., \& West, S. G. (2005). Teacher's corner: Testing measurement invariance of second-order factor models. Structural Equation Modeling, 12(3), 471492.

Chen, M. F., \& Tung, P. J. (2014). Developing an extended Theory of Planned Behaviour model to predict consumers' intention to visit green hotels. International Journal of Hospitality Management, 36, 221-230.

Chen, Y.-S., Lin, C.-Y., \& Weng, C.-S. (2015). The influence of environmental friendliness on green trust: The mediation effects of green satisfaction and green perceived quality. Sustainability, 7(8), 10135-10152.

Choi, H., Jang, J., \& Kandampully, J. (2015). Application of the extended VBN theory to understand consumers' decisions about green hotels. International Journal of Hospitality Management, 51(2015), 87-95.

Chong, H., \& Verma, R. (2013). Hotel sustainability: Financial analysis shines a cautious green light. Cornell Hospitality Reports, 13(10), 4-13.

Claudy, M. C., Garcia, R., \& O'Driscoll, A. (2015). Consumer resistance to innovation - A behavioural reasoning perspective. Journal of the Academy of Marketing Science, 43(3), 528-544.

Claudy, M. C., Peterson, M., \& O’Driscoll, A. (2013). Understanding the attitude-behavior gap for renewable energy systems using Behavioral Reasoning Theory. Journal of Macromarketing, 33(4), 273-287.

Claudy, M. C., \& Peterson, M. (2014). Understanding the underutilization of urban bicycle commuting: A behavioural reasoning perspective. Journal of Public Policy \& Marketing, 33(2), 173-187.

Cohen, J. (1988). Statistical Power Analysis for the Behavioural Science (2 ${ }^{\text {nd }}$ ed.). Hillsdale, NJ: Lawrence Erlbaum Associates.

Department of Statistics Malaysia. (2018). Current Population Estimates, Malaysia, 2017-2018. Retrieved October 23, 2019, from https://www.dosm.gov.my/v1/index.php?r=column 
/cthemeByCat\&cat=155\&bul_id=c1pqTnFjb29HSnNYNUpiTmNWZHArdz09\&menu_ id=L0pheU43NWJwRWVSZklWdzQ4TlhUUT09\#

Diamantopoulos, A., \& Siguaw, J. A. (2006). Formative versus reflective indicators in organizational measure development. A comparison and empirical illustration. British Journal of Management, 17(4), 263 -282.

Fishbein, M., \& Ajzen, I. (1975). Belief, Attitude, Intention and Behaviour: An Introduction to Theory and Research. Reading, MA: Addison-Wesley.

Fishbein, M., \& Ajzen, I. (2009). Predicting and changing behaviour: The reasoned action approach. New York: Psychology Press.

Gordon-Wilson, S., \& Modi, P. (2015). Personality and older consumers' green behaviour in the UK. Futures, 71, 1-10.

Gupta, A., \& Arora, N. (2017). Consumer adoption of m-banking: A behavioral reasoning theory perspective. International Journal of Bank Marketing, 35(4), 733-747.

Hair, J. J. F., Hollingsworth, C. L., Randolph, A. B., \& Chong, A. Y. L. (2017a). An updated and expanded assessment of PLS-SEM in information systems research. Industrial Management \& Data Systems, 117(3), 442-458.

Hair, J. F. Jr., Hult, G. T. M., Ringle, C., \& Sarstedt, M. (2014). A Primer on Partial Least Squares Structural Equation Modeling (PLS-SEM). Thousand Oaks, CA: Sage Publications.

Hair, J. F. Jr., Hult, G. T. M., Ringle, C., \& Sarstedt, M. (2017b). A Primer on Partial Least Squares Structural Equation Modeling (PLS-SEM) (2 ${ }^{\text {nd }}$ ed.). Thousand Oaks, CA: Sage Publications.

Hair, J. F., Sarstedt, M., Pieper, T. M., \& Ringle, C. M. (2012). The use of partial least squares structural equation modeling in strategic management research: A review of past practices and recommendations for future applications. Long Range Planning, 45(5), 320-340.

Han, H., Hsu, L. T., \& Lee, J. (2009). Empirical investigation of the roles of attitudes toward green behaviors, overall image, gender, and age in hotel customers' eco-friendly decision-making process. International Journal of Hospitality Management, 28(4), 519528.

Han, H., Hsu, L. T. \& Sheu, C. (2010). Application of the Theory of Planned Behavior to green hotel choice: Testing the effect of environmental friendly activities. Tourism Management, 31(3), 325-334.

Han, H., Hsu, L.-T. J., Lee, J.-S., \& Sheu, C. (2011). Are lodging customers ready to go green? An examination of attitudes, demographics, and eco-friendly intentions. International Journal of Hospitality Management, 30(2), 345-355.

Han, H., Hwang, J., Kim, J., \& Jung, H. (2015). Guests' pro-environmental decision-making process: Broadening the norm activation framework in a lodging context. International Journal of Hospitality Management, 47, 96-107.

Hoyle, R. H. (1995). The structural equation modeling approach: Basic concepts and fundamental issues. Thousand Oaks, CA: Sage.

Huang, H., Lin, T., Lai, M., \& Lin, T. (2014). Environmental consciousness and green consumer behavior: An examination of motivation crowding effect. International Journal of Hospitality Management, 40, 139-149. 
Jiang, Y., \& Kim, Y. (2015). Developing multi-dimensional green value extending social exchange theory to explore customers' purchase intention in green hotels-evidence from Korea. International Journal of Contemporary Hospitality Management, 27(2), 308334.

Kahneman, D., Slovic, P., \& Tversky, A. (1982). Judgment under uncertainty: Heuristics and biases. Science New Series, 185(4157), 1124-1131.

Kline, R. B. (2011). Principles and Practice of Structural Equation Modeling. New York: Guilford Press.

Laroche, M., Bergeron, J., \& Barbaro-Forleo, G. (2001). Targeting consumers who are willing to pay more for environmentally friendly products. Journal of Consumer Marketing, 18(6), 503-520.

Lee, J-. S., Hsu, L-. T., Han, H., \& Kim, Y. (2010). Understanding how consumers view green hotels: How a hotel's green image can influence behavioural intentions. Journal of Sustainable Tourism, 18(7), 901-914.

Li, M., \& Wei, W. (2013). Consumers' pro-environmental behavior and the underlying motivations: A comparison between household and hotel settings. International Journal of Hospitality Management, 32(1), 102-112.

Luchs, M. G., Naylor, R. W., Irwin, J. R., \& Raghunathan, R. (2010). The sustainability liability: Potential negative effects of ethicality on product preference. Journal of Marketing, 74(5), 18-31.

Manaktola, K., \& Jauhari, V. (2007). Exploring consumer attitude and behaviour towards green practices in the lodging industry in India. International Journal of Contemporary Hospitality Management, 19(5), 364-377.

Marsh, H. W., \& Hocevar, D. (1985). Application of confirmatory factor analysis to the study of self-concept: First-and higher order factor models and their invariance across groups. Psychological Bulletin, 97(3), 562-582.

Mas'od, A., \& Chin, T. A. (2014). Determining socio-demographic, psychographic and religiosity of green hotel consumer in Malaysia. Procedia - Social and Behavioral Sciences, 130, 479-489.

Mostafa, M. (2009). Shades of green: A psychographic segmentation of the green consumer in Kuwait using self-organizing maps. Expert Systems with Applications, 36(8), 1103011038

Nicholls, J., \& Schimmel, K. (2016). Satisfaction as reasons for and against generosity decisions: A behavioral reasoning theory exploration. The Marketing Management Journal, 26(2), 86-100.

Papaoikonomou, E., Ryan, G., \& Valverde, M. (2011). Mapping ethical consumer behavior: Integrating the empirical research and identifying future directions. Ethics and Behavior, 21(3), 197-221.

Park, J., \& Kim, H. (2014). Environmental proactivity of hotel operations: Antecedents and the moderating effect of ownership type. International Journal of Hospitality Management, $37,1-10$.

Park, M., Cho, H., Johnson, K., \& Yurchisin, J. (2017). Use of behavioral reasoning theory to examine the role of social responsibility in attitudes toward apparel donation. International Journal of Consumer Studies, 41(3), 333-339.

Pennington, N., \& Hastie, R. (1988). Explanation-based decision making: Effects of memory structure on judgment. Journal of Experimental Psychology: Learning, Memory, and Cognition, 14(3), 521-533. 
Podsakoff, P. M., MacKenzie, S. B., Lee, J. -Y., \& Podsakoff, N. P. (2003). Common method biases in behavioral research: A critical review of the literature and recommended remedies. Journal of Applied Psychology, 88(5), 879-903.

Podsakoff, P. M., \& Organ, D. W. (1986). Self-reports in organizational research: Problems and Prospects. Journal of Management, 12(4), 531-544.

Rahman, I., \& Reynolds, D. (2016). Predicting green hotel behavioral intentions using a theory of environmental commitment and sacrifice for the environment. International Journal of Hospitality Management, 52, 107-116.

Rahman, I., \& Reynolds, D. (2017). The influence of values and attitudes on green consumer behavior: A conceptual model of green hotel patronage. International Journal of Hospitality \& Tourism Administration, $20(1), \quad$ 47-74. https://doi.org/10.1080/15256480.2017.1359729

Ramayah, T., Cheah, J., Chuah, F., Ting, H., \& Memon, M. A. (2018). Partial Least Squares Structural Equation Modelling (PLS-SEM) using SmartPLS 3.0, Kuala Lumpur, Malaysia: Pearson.

Ringle, C. M., Wende, S., \& Becker, J.-M. (2015). SmartPLS 3. Bönningstedt: SmartPLS. Retrieved June 6, 2019, from http://www.smartpls.com

Rivera, J., \& de Leon, P. (2005). Chief executive officers and voluntary environmental performance: Costa Rica's certification for sustainable tourism. Policy Sciences, $38(2 / 3), 107-127$.

Schultz, P. W., Shriver, C., Tabanico, J. J., \& Khazian, A. M. (2004). Implicit connections with nature. Journal of Environmental Psychology, 24(1), 31-42.

Sivathanu, B. (2018). Adoption of internet of things (IOT) based wearables for elderly healthcare - A behavioural reasoning theory (BRT) approach. Journal of Enabling Technologies, 12(4), 169-185. https://doi.org/10.1108/JET-12-2017-0048

Stern, P. C., Dietz, T., \& Kalof, L. (1993). Value orientations, gender, and environmental concern. Environment and Behavior, 25(5), 322-348.

Sukhu, A., \& Scharff, R. (2018). Will 'doing right' lead to 'doing well'? An examination of green behaviour. Journal of Consumer Marketing, 35(2), 169-182.

Tan, B. C., \& Yeap, P. F. (2012). What drives green restaurant patronage intention? International Journal of Business Management, 7(2), 215- 223.

Tang, C., \& Lam, D. (2017). The role of extraversion and agreeableness traits on Gen Y's attitudes and willingness to pay for green hotels. International Journal of Contemporary Hospitality Management, 29(1), 607-623.

Teng, C. C., \& Chang, J. H. (2014). Effects of temporal distance and related strategies on enhancing customer participation intention for hotel eco-friendly programs. International Journal of Hospitality Management, 40, 92-99.

Teng, Y. M., Wu, K. S., \& Liu, H. H. (2013). Integrating altruism and the theory of planned behavior to predict patronage intention of a green hotel. Journal of Hospitality \& Tourism Research, 39(3), 299-315.

Tetlock, P. E., Skitka, L., \& Boettger, R. (1989). Social and cognitive strategies for coping with accountability: Conformity, complexity, and bolstering. Journal of Personality and Social Psychology, 57(4), 632-640.

Tourism Malaysia. (2016). ATF 2016 Showed Progress in ASEAN Tourism Cooperation. Retrieved October, 23, 2016, from https://www.tourism.gov.my/media/view/atf-2016. 
Verma, V. K., \& Chandra, B. (2018). An application of theory of planned behavior to predict young Indian consumers' green hotel visit intention. Journal of Cleaner Production, $172,1152-1162$.

Westaby, J. D. (2005a). Behavioural reasoning theory: Identifying new linkages underlying intentions and behaviour. Organisational Behaviour and Human Decision Processes, 98, (2005), 97-120.

Westaby, J. D. (2005b). Comparing attribute importance and reason methods for understanding behavior: An application to internet job searching. Applied Psychology, 54(4), 568-583.

Westaby, J. D., Probst, T. M., \& Lee, B.C. (2010). Leadership decision-making: A behavioral reasoning theory analysis. The Leadership Quarterly, 21(2010), 481-495.

World Population Review. (2019). Kuala Lumpur Population, 2019. Retrieved October 23, 2019, from http://worldpopulationreview.com/world-cities/kuala-lumpur-population/

Yadav, R., \& Pathak, G. S. (2016). Young consumers' intention towards buying green products in a developing nation: Extending the theory of planned behavior. Journal of Cleaner Production, 135, 732-739.

Yadav, R., \& Pathak, G. S. (2017). Determinants of consumers' green purchase behaviour in a developing nation: Applying and extending the theory of planned behavior. Ecological Economics, 134(2017), 114-122.

Yusof, Z. B., \& Jamaludin, M. (2014). Barriers of Malaysian green hotels and resorts. ProcediaSocial and Behavioral Sciences, 153, 501-509. 